\title{
MARKO ZAJC \\ Administrative Legacy and the River Mura Border Dispute between Slovenia and Croatia
}

\begin{abstract}
Set at the intersection between political history and environmental history, this article shows the significance of administrative legacy and natural dynamics of rivers in the landscape for creating (and solving) border disputes. In 2006, Slovenia and Croatia engaged in such a dispute regarding the exact course of the border near the River Mura in the vicinity of the villages of Hotiza (Slovenia) and Sv. Martin na Muri (Croatia). After giving an overview of the Slovenian-Croatian border disputes between 1992 and 2019, the author analyses the border dispute around the River Mura. He then shows how the history of the river's regulations, of the Habsburg and Yugoslav land survey activities, as well as of the previous border disputes on the river are entangled in the current dispute.
\end{abstract}

Marko Zajc is a Research Associate at the Institute of Contemporary History, Ljubljana.

\section{Introduction}

The Slovenian-Croatian border dispute is a longue durée phenomenon. It was born as collateral damage from the dissolution of socialist Yugoslavia in 1991 and has been fuelled by Slovenian and Croatian nationalist discourses ever since. Although the Slovenian-Croatian row over the course of the state border that runs between them seems at first glance to resemble the disputes that 'helped' to dissolve Yugoslavia, it in fact has a completely different character. The concept of 'border dispute' in the final years of socialist Yugoslavia did not refer to disputes with regard to the layout of its inner borders, but rather to disagreements about whether the borders between the Yugoslav republics were merely 'administrative' or also 'historical'. ${ }^{1}$ Were the republics entitled to statehood, or were they merely administrative units? The Yugoslav

\footnotetext{
${ }^{1}$ Bogo Grafenauer, Jugoslovanske medrepubliške in zunanje meje. 'Administrativne' ali zgodovinsko zrasle, Glasnik Slovenske matice 15, no. 1-2 (1991), 4-10.
} 
crisis of the 1980s was not one of internal borders, but of internal spaces. ${ }^{2}$ The dispute between Slovenia and Croatia after 1991 is different. It started because the former border between the two socialist republics had been drawn in various ways, ${ }^{3}$ or had not been drawn at all. ${ }^{4}$ The dispute therefore focused on the concrete borderline and its interpretations rather than on the nature of the political spaces.

This study addresses the intersections of administrative legacy and the natural dynamics of border rivers as vital factors in the creation of border disputes. The 2006 border dispute between Slovenia and Croatia serves as a starting point for a comprehensive analysis of the history of environmental changes of the River Mura and the associated bordering practices. History, in this case, is not just a pre-story, but a precondition for understanding the contemporary border issues. As I show in the following, the concept of 'phantom borders', designed to study the effects of former political borders on present societies, is also relevant in approaching existing borders, especially if, as in this case, the history of the environment and of administrative practice plays a significant role.

\section{The Slovenian-Croatian Border Dispute after 1991}

Public attention has been drawn mostly to the maritime border dispute between Slovenia and Croatia, although there are several disputed sections on the land borderline as well, causing problems for the local population. ${ }^{5}$ Slovenia possesses a tiny Adriatic coastline, $46 \mathrm{~km}$ long. This sea component makes the Slovenian-Croatian border an issue of national importance. A SlovenianCroatian maritime border never existed in Yugoslavia; what did exist, however, was the administrative practice of (federal) police supervision over the waters of the Adriatic Sea. In this context, the Slovenian side supervised the

\footnotetext{
${ }^{2}$ Holm Sundhaussen, Jugoslawien und seine Nachfolgestaaten 1943-2011. Eine ungewöhnliche Geschichte des Gewöhnlichen, Wien et al. 2012, 203; Victor Meier, Yugoslavia. A History of Its Demise, London, New York 1999, 83-85.

${ }^{3}$ Damir Josipovič, Slovensko-hrvaška meja. Izbrane problematizacije političnega in etničnega razmejevanja, in: Darko Darovec/Petar Strčić, eds, Slovensko-hrvaško sosedstvo. Hrvatsko-slovensko susjedstvo, Koper 2011, 227-248, 230.

${ }^{4}$ Darja Mihelič, Piranski zaliv. Nekoč sobivanje, danes prepir. Izbrane problematizacije političnega in etničnega razmejevanja, in: Darovec/Strčić, eds, Slovensko-hrvaško sosedstvo, 105-128, 120.

${ }^{5}$ Marko Zajc, The Border Monster Refuses to Die, Südosteuropa. Journal of Politics and Society 66, no. 1 (2018), 119-130, DOI: 10.1515/soeu-2018-0007; Marina Vokić Žužul/ Valerija Filipović, Granice podmorskih prostora jadranskih država, Poredbeno pomorsko pravo 54 , no. 169 (2015), 9-56, https://hrcak.srce.hr/144383; Mladen Klemenčić/ Duško Topalović, Morske granice u Jadranskome moru, Geoadria 14, no. 2 (2009), 311-324, DOI: 10.15291/geoadria.555. All internet references were accessed on 9 October 2019.
} 
entire Bay of Piran. ${ }^{6}$ Disagreements over the border appeared soon after independence. ${ }^{7}$ In March 1992, the Croatian government decided to ban Slovenian fishermen from fishing in Croatian waters, ${ }^{8}$ and the undefined border at sea then encouraged further border incidents. In July 1992, Croatian police seized two Slovenian fishing ships. ${ }^{9}$ In 1992/1993, Croatia and Slovenia clarified their interpretations of the border in the Bay of Piran: the Croatian government claimed that the 'true' maritime border lies in the middle of the Bay of Piran, ${ }^{10}$ while the Slovenian side argued for the implementation of the principle of $u t i$ possidetis, which would acknowledge the fact that Slovenia had exercised jurisdiction over the Bay of Piran during Yugoslav times. ${ }^{11}$

Border incidents started to appear on the land border, too. In February 1993, a dispute broke out over the exploitation of forests in the border area near Kočevje, in southwestern Slovenia. The issue of the border in the early years of independence seemed to be connected to other open bilateral questions between the two countries, such as the ownership of a brewery in the town of Buzet in Croatia, and the issue of the obligations of the Bank of Ljubljana (Ljubljanska banka) to return hard currency savings to clients now living in Croatia. ${ }^{12}$ The two countries succeeded in establishing a 'Mixed Diplomatic Commission for the Establishment and Demarcation of the SlovenianCroatian Border and the Final Agreement on the Border' (1993-98), which proposed solutions to the land boundary problem, except in four disputed areas. After a brief episode of unsuccessful mediation by former US defence minister William Perry in 1999, bilateral talks resumed. ${ }^{13}$ These resulted in a 'Treaty on the Common State Border', the so-called 'Drnovšek-Račan Agreement' (named after the two countries' then serving prime ministers), confirmed by

\footnotetext{
${ }^{6}$ Drago Kladnik/Primož Pipan/Primož Gašperič, Poimenovanja Piranskega zaliva, Ljubljana 2014, 70.

${ }^{7}$ Renata Jambrešić Kirin/Domagoj Račić, Claiming and Crossing Borders. A View on the Slovene-Croatian Border Dispute, Društvena istraživanja 25, no. 4 (2016), 433-453, DOI: 10.5559/ di.25.4.01.

${ }^{8}$ Darijan Košir, Po 1. aprilu prepoved ribolova na Hrvaškem, Delo, 19 March 1992.

9 Boris Šuligoj, Hrvaška pomorska policija ustavila Delamarisovi ladji, Delo, 15 July 1992.

${ }^{10}$ Zvonko Gržetić/Vesna Barić Punda/Valerija Filipović, O granicama u sjevernom Jadranu, 1948-2009. S posebnim osvrtom na kronološki kartografski prikaz, Poredbeno pomorsko pravo 49, no. 164 (2010), 19-72, 38, https://hrcak.srce.hr/63255; Tatjana Tomaić, Kriza međunarodnih odnosa. Studija slučaja: Hrvatska i Slovenija. Granica u Istri, Časopis za suvremenu povijest 43, no. 2 (2011), 391-414, https://hrcak.srce.hr/74008.

${ }_{11}$ Arhiv Hrvatske akademije znanosti i umjetnosti, AHAZU 652, 2.2 Razgraničenje sa Slovenijom, Memorandum o Piranskem zalivu, 7 April 1993.

${ }_{12}$ Kronologija leta 1993, in: Tit Doberšek, ed, Slovenski almanah 94', Ljubljana 1993, 7-31, 23.

${ }^{13}$ Thomas Bickl, Reconstructing the Intractable. The Croatia-Slovenia Border Dispute and Its Implications for EU Enlargement, Croatian Political Science Review 54, no. 4 (2017), 7-39, 11-16, https://hrcak.srce.hr/190336.
} 
both governments on 19 July 2001, and then refused by the Croatian side in September 2002. ${ }^{14}$

In the 2000s, the European Union (EU) proved to be a decisive factor. ${ }^{15}$ Slovenia gained EU membership in 2004, and in 2007 entered the Schengen border regime. ${ }^{16}$ In December 2008, Slovenia blocked further EU accession talks with Croatia, because of the documents (maps) that might prejudice the common border in favour of Croatia. ${ }^{17}$ In November 2009, both governments signed an Arbitration Agreement. They submitted their border disputes to the Permanent Court of Arbitration (PCA) in The Hague, and Croatia was allowed to proceed with its EU accession process. It became an EU member in June 2013. The fact that Slovenia had used its position as someone already 'in' the club to block Croatia, still 'out' but eager to join, proved to yield consequences. In July 2015, the Serbian and Croatian newspapers Kurir and Večernji list published audio recordings of telephone conversations between the agent on the Slovenian side and the arbitrator Jernej Sekolec. ${ }^{18}$ According to tribunal rules, all PCA arbitrators, including the Slovenian and Croatian ones, were to be neutral about the arbitration process and were to acknowledge only legal and meritocratic criteria. Although the PCA in The Hague decided that the incident had no significant consequences for the arbitration process and carried on with its procedures, Croatia immediately rejected the arbitration as soon as it was issued. ${ }^{19}$

The Final Award of the PCA on the Slovenian-Croatian border was announced on 29 June 2017. It is impossible to discuss its complicated content in detail here. However, Slovenia gained more than three-quarters of the Bay of Piran. A 'junction area' was to be established between the Slovenian territorial sea and the High Seas. For this study, it is important to point out that Croatia gained most of the disputed territory on the land border. With minor exceptions, the PCA considered the borders of the cadastral municipalities

\footnotetext{
${ }^{14}$ Vasilka Sancin, Slovenia-Croatia Border Dispute. From 'Drnovšek-Račan' to 'PahorKosor' Agreement, European Perspectives. Journal on European Perspectives of the Western Balkans 2, no. 2 (2010), 93-111.

${ }^{15}$ Višeslav Raos, Pomicanje granice Europske unije na jugoistok i višestruki procesi teritorijalizacije, Politička misao 50, no. 3 (2013), 33-55.

16 Saša Šegović, Šengenski režim upravljanja vanjskim granicama EU, Zbornik radova Pravnog fakulteta u Splitu 48, no. 1 (2011), 11-31, https://hrcak.srce.hr/66400.

${ }_{17}$ Marko Zajc, The Slovenian-Croatian Border. History, Representations, Inventions, Acta Histriae 23, no. 3 (2015), 499-510.

${ }_{18}$ Sandra Veljković, Donosimo audiosnimku razgovora arbitra i slovenske predstavnice! Poslušajte!, Večernji list, 22 July 2015, https://www.vecernji.hr/premium/ekskluzivno-donosimorazgovor-arbitra-i-slovenske-strane-poslusajte-snimke-1015908.

19 Milanović: Arbitraža sa Slovenijom ne postoji, Aljazeera Balkans, 1 October 2015, http:// balkans.aljazeera.net/vijesti/milanovic-arbitraza-sa-slovenijom-ne-postoji.
} 
as the most important argument for the definition of the borderline. ${ }^{20}$ Since then, the Croatian side has been trying to convince the international community (notably the EU) that the PCA's decision does not bind Croatia, due to the arbitration process having been corrupted through the Slovenian breach of rules by means of the illicit telephone conversations. The Slovenian side has stubbornly continued to advocate the Final Award of the PCA as the only legal, internationally binding, and 'European' solution to the border question. ${ }^{21}$ Thus, the conflict continues, accompanied by occasional sensational revelations in the media about the eavesdropping activities of the Croatian or Slovenian secret services. ${ }^{22}$ Not surprisingly, political scientists have noted that the impact of the dispute on the EU enlargement process has been profound. Thomas Bickl, for example, concludes his detailed analysis of the dispute by saying that 'any of those bilateral issues must be solved ahead of EU accession to avoid Member States from using their "inside-the-club" status to enforce their position vis-à-vis Candidate Countries through outright blackmailing'.23

\section{The Border Dispute at the River Mura}

Two major transnational rivers define the northeastern part of the Slovenian-Croatian boundary line, which delimits the Podravje and Pomurje regions (Slovenia) from the Varaždin and Međimurje counties (Croatia) -the Drava (in German Drau, in Hungarian Dráva) and the Mura (in German Mur). For the wider area, a high level of economic interdependence in agriculture, trade, and small-scale industries is characteristic on both sides of the border. ${ }^{24}$ Soon after independence, Slovenian geodesists identified this section of the border as problematic, as they deemed it difficult to define the exact border-

\footnotetext{
${ }^{20}$ Permanent Court of Arbitration, Tribunal Determines Land and Maritime Boundaries in Final Award, PCA Press Release, The Hague, 29 June 2017, 13, https://pcacases.com/web/ sendAttach/2173.

${ }^{21}$ Zajc, The Border Monster Refuses to Die, 119-130.

${ }^{22}$ Aleksander Pozvek / Miha Orešnik, Hrvaška želela s prisluškovanjem nadzirati POP TV, 24ur.com, 8 April 2019, https://www.24ur.com/novice/svet/hrvaska-zelela-s-prisluskovanjemnadzirati-pop-tv.html.

${ }^{23}$ Bickl, Reconstructing the Intractable, 32.

${ }^{24}$ Aleksander Lorenčič, Slovensko-hrvaški (obmejni) odnosi v Spodnjem Podravju, in: Marko Zajc, ed, Ustvarjanje slovensko-hrvaške meje, Ljubljana 2018, 189-204, 191; Borut Belec, Hrvaška zemljiška posest v občini Lendava kot sestavina mejne problematike, Dela. Oddelek za geografijo Filozofske fakultete v Ljubljani 12 (1997), 183-193; Andrea Talan, Čovjek i Mura. Moguća istraživačka pitanja, Ekonomska i ekohistorija. Časopis za gospodarsku povijest i povijest okoliša 9, no. 1 (2013), 67-80, https://hrcak.srce.hr/114485.
} 


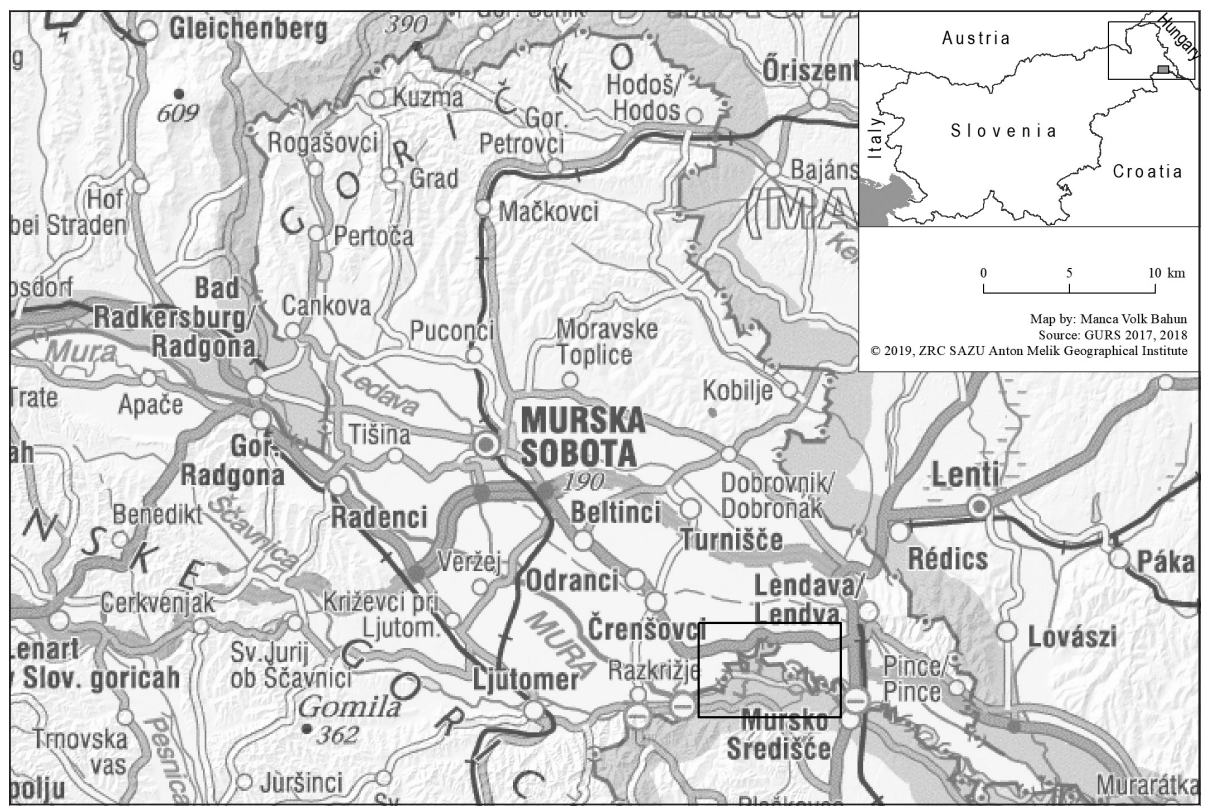

Figure 1: The wider region of the border dispute

line with Croatia. ${ }^{25}$ The ever-changing watercourses, as well as the man-made regulation of the rivers, had continually been shaping the lowland landscape of the wider area, and had thus provided various opportunities for border disputes to emerge. In fact, the exact boundary on this section of the border had never been defined or agreed upon by both countries, thus producing an environment conducive to border incidents. ${ }^{26}$

In January 1998, the Croatian authorities confiscated a van owned by the Slovenian intelligence service, which they had located on Croatian territory near the Slovenian village of Zavrč, on the River Drava. The incident caused significant embarrassment to the Slovenian security establishment: the minister of defence was forced to resign. ${ }^{27}$ On the undefined border section on the River Mura, the first major incident occurred in early March 2000. The area in which the incident took place, located on the left side of the River Mura,

${ }^{25}$ Božo Demšar, Ureditev državne meje Slovenije s Hrvaško, Geodetski vestnik 36 (1992), no. 4, 298-303.

${ }^{26}$ Pavel Zupančič, Zemljiški kataster in njegov pomen pri določanju državne meje, in: Vincenc Rajšp / Duša Krnel Umek / Pavel Zupančič, eds, Vprašanje oblikovanja slovenskega etničnega in državnega prostora s posebnim poudarkom na slovensko-hrvaški meji v Istri, Ljubljana 1998, 37-44, 42.

${ }_{27}$ Pregled dogodkov po svetu in doma, in: Aleš Stergar, ed, Slovenski almanah 99', Ljubljana 1998, 25-74, 32. 
was disputed because it was part of the Croatian cadastre, but at the same time had been under the jurisdiction of the Slovenian police until 1993. In that year, the Slovenian authorities had transferred control over the area of the Croatian cadastre on the left side of the River Mura to the Croatian police. On 3 March 2000, the Croatian police patrol arrested three inhabitants of the Slovenian village of Hotiza, who were working in the disputed forest, because they had allegedly entered Croatian territory illegally. The Croatian police were confronted with the resistance of furious Hotiza villagers, who blocked the road leading to Croatia through the territory of the Slovenian cadastre and demanded the release of the captured villagers. The incident ended with open passage being granted to the Croatian police and with the release of the arrested Slovenian locals. ${ }^{28}$ It happened only a couple of days after a parliamentary delegation from Croatia had paid an official visit to Ljubljana. In Croatia, the central-left government of Ivica Račan had recently ended the decade of nationalist leadership by Franjo Tuđman, and the visit had been praised as 'a signal of goodwill to solve most of the controversial issues'.29 After the border incident, however, Slovenian-Croatian relations returned to the mutual policy of irreconcilable positions and diplomatic protests.

On the River Mura, a series of incidents began in May 2005 when the Croatian authorities confiscated a ferry owned by the inhabitants of the village of Hotiza. The ferry had been in operation for more than two decades and was used by Slovenian farmers in order to reach the land on the other side of the river. On the very next day, a Croatian ferry started to operate, using the infrastructure built by the Slovenian community. Slovenian officials protested, but the Slovenian ferry remained grounded. Local Slovenian member of parliament Jožef Horvat of the New Slovenia - Christian Democrats party (Nova Slovenija - Krščanski demokrati, NSi) stated that the ferry was not just a means of transportation, but also 'a symbol of Slovenian identity for the villagers of Hotiza' ${ }^{30}$ The Slovenian entrepreneur who operated the ferry had a different opinion: he took over the operation of the Croatian ferry instead. ${ }^{31}$

A few months earlier, in March 2005, the Croatian side had started building a bridge across the Mura without any agreement from Slovenia. The Slovenian authorities protested more than once; according to Slovenian water experts, the bridge compromised local flood safety. ${ }^{32}$ When the Mura flooded in August 2005, new embankments needed to be constructed on both banks of the river in order to improve flood safety. But who would do the construc-

\footnotetext{
${ }^{28}$ Ivan Gerenčer, Incident ob Muri vznemiril prebivalstvo, Delo, 3 March 2000, 1.

${ }^{29}$ Veso Stojanov, Hrvaški signali, Delo, 28 February 2000, 1.

${ }^{30}$ Hrvati zaplenili slovenski brod na Muri in splavili svojega, Dnevnik, 6 May 2005, https:// www.dnevnik.si/124059.

${ }^{31}$ Milena Dora, Je Krompir, Dnevnik, 6 September 2006, https://www.dnevnik.si/199217.

${ }^{32}$ Simon Balažic, Meja na Muri, Mišičev vodarski dan 17 (2006), 38-42, 41.
} 
tion in the territory under dispute? Towards the end of August 2006, the Croatian side started building embankments on the left bank of the Mura, in the Croatian cadastre, without asking for authorization from the Slovenian government. After a meeting of both prime ministers in the disputed territory on 2 September 2006, an agreement was reached on the joint construction of embankments on the River Mura, and the issue vanished from the media. Not for long, however. The border dispute peaked on 13 September 2006, when the Croatian police detained a few Slovenian journalists for alleged illegal crossing of the state border. The Slovenian authorities reacted immediately and with force, deploying a fully outfitted special police unit at the border. ${ }^{33}$ The Slovenian police lined up at the cadastral border and crossed it as well. They dug up a newly constructed road and brought down two trees. This road was within the borders of the Croatian cadastre, linking the hamlet of Murišče with the Croatian side. The hamlet had been entered into the Slovenian Register of Spatial Units, but was within the Croatian cadastre. ${ }^{34}$ The conflict settled down after an agreement was reached on 15 September 2006 by the 'Slovenian-Croatian Commission for Water Management' on the joint restoration of the high-water embankment between Hotiza and the hamlet of Kot, on the left bank of the Mura. ${ }^{35}$

A media analysis of this 2006 conflict shows the importance of representation when it comes to border rivers. Croatia seemingly equated the state border with the cadastral border. Meanwhile, for the Slovenian leadership, the cadastral border represented merely one of several criteria for defining the state border. While the Croatian media reported on the cadastre as the indisputable border between the two states, ${ }^{36}$ the Slovenian media relativized the significance of the cadastral border. A correspondent for the daily Dnevnik, for example, claimed that the disputed territory may well have been a part of the Croatian cadastre, but that it was nevertheless 'sovereign Slovenian territory'. ${ }^{37}$ If the Slovenian media were appalled at the Croatian construction projects on the left bank of the Mura, the Croatian media were horrified at the presence of Slovenian police on the territory of the Croatian cadastre. The Slovenian

\footnotetext{
${ }_{33}$ Novinarje so pridržali, na meji specialci, Dnevnik, 14 September 2006, https://www. dnevnik.si/200800/slovenija/200800.

${ }^{34}$ Regulacija Mure izvor nesoglasij, Dnevnik, 15 September 2006, https://www.dnevnik. si/200998/slovenija/200998.

35 Zapisnik XI. Zasedanja Stalne slovensko-hrvaške komisije za vodno gospodarstvo, Ljubljana, 9/10 June 2015, http://www.statika.evode.gov.si/fileadmin/vg_komisije/SLO-CRO_ zasedanje\%2011_junij\%202015.pdf.

${ }^{36}$ Vlado Zagorac/Ivica Beti, Slovenski specijalci zauzeli položaje uz granicu s Hrvatskom, Večernji list, 14 September 2006, https://www.vecernji.hr/vijesti/slovenski-specijalcizauzeli-polozaje-uz-granicu-s-hrvatskom-823504.

${ }_{37}$ Boris Cipot, 'Hrvati so si privoščili še eno provokacijo', Dnevnik, 28 August 2006, https:// www.dnevnik.si/197495/lokalno/197495.
} 
media that were critical of nationalism reacted indignantly to the border disputes in general as well as to the demonstration of force. ${ }^{38}$ Meanwhile, the British Broadcasting Corporation (BBC) asked itself, in line with orientalist stereotypes, whether a new war might break out in the Balkans, as the Slovenian Press Agency reported. ${ }^{39}$

In order to at least superficially understand the Hotiza border dispute, both politicians and journalists were forced to get acquainted with the basics of local geography, history, and water management interventions. The border dispute turned out to be more complicated than it appeared at first glance. The situation on the ground could not be resolved without knowledge of cadastre issues, consolidations of river banks, local administrative delimitations, and geographical features of the landscape.

\section{The Environmental History of the River Mura}

The Mura is part of the Black Sea drainage basin, a left-bank tributary of the River Drava. It is a snow-fed river system and belongs among the lowland rivers, characterized by frequent river bed changes on the flood plains, meandering, and frequent floods. The frequency and scope of the latter have been anthropogenically reduced by means of several hydro accumulation dams before the river reaches Slovenia. In its totality, the Mura is $465 \mathrm{~km}$ long. It flows through Slovenia for a total length of $95 \mathrm{~km}$, and the section of the Slovenian inner Mura, that is the section without the status of border river, is approximately $33 \mathrm{~km}$ long. ${ }^{40}$ The Mura represents a border for a total length of $115 \mathrm{~km}$, that is $25 \%$ of the whole river. First, it divides Slovenia and Austria between the villages of Ceršak and Petanjci, for a distance of over $33 \mathrm{~km}$; then Slovenia and Croatia between Gibina and Krka (almost $34 \mathrm{~km}$ ); and finally, Hungary and Croatia for a distance of $48 \mathrm{~km}$ from Krka until it flows into the River Drava, which 'takes over' representing the borderline between the two countries. ${ }^{41}$ While this study focuses on the River Mura border between Slovenia and Croatia, it does include aspects of the River Mura border between Slovenia and Austria as well as the Slovenian inner Mura.

\footnotetext{
38 Ali H. Žerdin, Napeti petelini, Mladina, 21 September 2006, https://www.mladina.si/ 92602/napeti-petelini/.

${ }^{39}$ BBC: Hotiza povod za nov konflikt na Balkanu, Slovenska tiskovna agencija, 18 September 2006, https://www.sta.si/1088579/bbc-hotiza-povod-za-nov-konflikt-na-balkanu-18-9.

${ }^{40}$ Jožef Novak / Vladimir Vratarič, Mura nekoč, danes, jutri, Mišičev vodarski dan 14 (2003), 113-125, 119.

${ }^{41}$ Balažic, Meja na Muri, 38.
} 
Due to the hydrological characteristics and lowlands environment, the downstream part of the Mura has continuously changed. ${ }^{42}$ Hydrologists describe it as a type of meandering, braided river, whose channel typically consists of a network of small canals. The majority of the water does flow through its main river bed, but diversions result in new main canals, while the old main canals turn into side canals. The Mura not only 'moves', but changes its form as well. According to historian Andrej Hozjan, south of the town of Radgona (German Radkersburg) the river has continued to create many new branches, and the maps from the times of Habsburg emperor Joseph II (176590) reveal all sorts of river bed changes. ${ }^{43}$ The rate of flow ratio was supposedly, according to the Josephine maps, $40 \%$ of water in the main canal versus $60 \%$ of water in the branches. ${ }^{44}$

Hydrological literature places the first unsystematic measures addressing the river's water regime management in the $16^{\text {th }}$ century. The goal then was to protect the settlements and allow for the navigation of the River Mura. On the Hungarian side, legislation on securing the banks in order to protect the local settlements was in force by the $17^{\text {th }}$ century. The Mura's river bed was surveyed (1753), and, on the basis of these surveys, a few meanders were shortened and the river banks secured. ${ }^{45}$

Until 1918, the section of the Mura between Radgona and Gibina was a border river between Austria and Hungary, while from Gibina to its mouth it had the status of a Hungarian inner river. In 1810, the meander near Razkrižje was shortened in order to protect the settlement from the annual floods. In 1822, the Mura created a new water canal near Mursko Središće. Thus, the bridge found itself on dry land and regulation was necessary in order to steer the Mura back to its old river bed. In the second half of the $19^{\text {th }}$ century, then, the first large-scale regulation took place. In 1874, the government in Vienna took the decision to finance the regulation of three sections of the River Mura south of Graz on the territory of present-day Austria, the so-called Hohenburg Regulation of 1874-91.46

With the dissolution of the Habsburg Monarchy in 1918, the works on the River Mura stopped. Due to the abandonment of maintenance works on the section between Špilj and Radgona, which after 1919 had come to designate the new border between the Republic of Austria and the Kingdom of Serbs, Croats, and Slovenes, certain sections of the Mura broadened significantly, to

\footnotetext{
${ }^{42}$ Sandra Kantar/Marjana Ivanek-Martinčić/Zvjezdana Augustinović, Mura. Čovjek. Priroda, Podravina 7, no. 14 (2008), 147-158, 148, https://hrcak.srce.hr/77934.

${ }_{43}$ Andrej Hozjan, Reka Mura na Slovenskem v novem veku, Ekonomska i ekohistorija. Časopis za gospodarsku povijest i povijest okoliša 9, no. 1 (2013), 16-27, 17, https://hrcak.srce.hr/114477.

${ }_{44}$ Balažic, Meja na Muri, 40.

${ }^{45}$ Balažic, Meja na Muri, 40.

${ }^{46}$ Novak/Vratarič, Mura nekoč, danes, jutri, 115.
} 
up to 200 metres in width. Due to the neglect of its banks, the Mura flooded several times between 1918 and 1926. The poor state of the Mura's river bed in 1926 prompted the establishment of the 'Interstate Austrian-Yugoslav Commission for the Regulation of Mura' in Maribor, tasked with managing all works on the (border) river. The two states agreed that each would restore the extensive embankments on their respective sides, and would share the expenses for the works required in the river bed itself. These works were concluded in 1937/38, and since then the Mura's flow rate has increased significantly. ${ }^{47}$ Despite everything, the 1938 floods were catastrophic, and the Mura engulfed more than forty villages. ${ }^{48}$

The period of socialist Yugoslavia after 1945 saw the most significant investments in the water infrastructure in the Pomurje region. The LedavaMura dry relief canal-the River Ledava being a tributary of the Mura-was constructed between 1948 and 1958 in order to prevent floods in the town of Murska Sobota. The other tributaries of the River Mura were gradually regulated and dammed as well. ${ }^{49}$ By the end of the 1980s, three accumulations (lakes) and a single dry reservoir were constructed on each side of the Mura. ${ }^{50}$ By the time of Yugoslavia's dissolution in 1991, the Pomurje region had become, in the sense of its watercourses, a completely artificially regulated landscape, with canals, embankments, and artificial lakes that had not existed previously. The secondary river branches and marshes had largely disappeared from the landscape.

However, human interventions in the nature of the River Mura and its tributaries have also resulted in unforeseen ecological consequences. The width of the river was narrowed to as little as 60-80 metres by means of hydrological interventions. These processes have resulted in a greater speed of the river and a more significant power of erosion. Due to the fortified banks, the river's erosion power can no longer be distributed throughout its bed. Instead, all of the energy goes towards deepening the river bed. ${ }^{51}$ Consequently, the groundwater level in the whole of the Mura drainage basin has been decreasing; the groves by the river have been drying out, and the drinking water reserves have been diminishing. ${ }^{52}$ Presently, experts advise widening the river basin and constructing side branches, to relieve the river's force. ${ }^{53}$ If repeated attempts were made to 'capture' the Mura into a single fortified river bed for

\footnotetext{
${ }^{47}$ Novak/Vratarič, Mura nekoč, danes, jutri, 116.

${ }^{48}$ Velika poplava, Slovenski gospodar, 1 June 1938, 7.

${ }^{49}$ Novak/Vratarič, Mura nekoč, danes, jutri, 118, 119.

${ }^{50}$ Novak/Vratarič, Mura nekoč, danes, jutri, 120.

${ }^{51}$ Aleš Lesjak, Mura skozi čas, Mišičev vodarski dan 25 (2014), 183-190, 188.

${ }^{52}$ Novak/Vratarič, Mura nekoč, danes, jutri, 121.

53 Norbert Baumann et al., Načelna vodnogospodarska zasnova za mejno Muro, I. Faza, Graz 2001, 5.
} 
more than three centuries, in the last few decades measures have been initiated to undertake a (limited) reconstruction of the pre-regulation conditions. ${ }^{54}$

On the Slovenian-Croatian border, the river is-in comparison to its section bordering Austria-still quite natural, a moderately altered watercourse. A few sections of this part of the river have been regulated as well, due to the risk of flooding. ${ }^{55}$ Extensive works aimed at systematically regulating the river in the territory of Slovenia were carried out between 1972 and 1990, up to the town of Bakovci, south of Murska Sobota. On another section, located downstream from Mursko Središće, on the border between Croatia and Slovenia east of the mentioned Hotiza, individual meanders were separated from the main river bed. ${ }^{56}$ The main works (canals) here were carried out from the 1960s onwards, until as late as 1990. Slovenia and Croatia worked jointly and in accordance with a 50:50 system, regardless of the cadastral border. Supposedly, hydrologists at that time were to observe the rule that the left bank is of Slovenian and the right bank of Croatian responsibility. ${ }^{57}$ In fact, the Final Award of the Permanent Court of Arbitration of 29 June 2017 quotes a document from 1967 that mentions the project of regulating the Mura through building canals near the village of Hotiza. ${ }^{58}$

Rivers as transnational natural phenomena with their unpredictable 'lives' tend to force political entities to engage in long-term cooperation. In 1954, Yugoslavia and Austria renewed the permanent bilateral commission for the River Mura. After it attained independence, the Republic of Slovenia ratified this agreement in $1993 .{ }^{59}$ It is thus relevant for the most recent history that since their independence, Croatia and Slovenia have formed no such bilateral commission concerning the River Mura. However, they did agree, in 1996, to establish a 'Permanent Slovenian-Croatian Commission for Water Management'. The accord on how this commission was to act was ratified by the two

\footnotetext{
${ }^{54}$ Baumann et al., Načelna vodnogospodarska zasnova za mejno Muro, 17.

55 Balažic, Meja na Muri, 40.

${ }^{56}$ Mitja Brilly et al., Hidrološka študija reke Mure, Mišičev vodarski dan 20 (2011), 155-163, 158.

57 Balažic, Meja na Muri, 40.

${ }^{58}$ PCA Case No. 2012-04, In the Matter of an Arbitration under the Arbitration Agreement between the Government of the Republic of Croatia and the Government of the Republic of Slovenia, Signed on 4 November 2009 between the Republic of Croatia and the Republic of Slovenia, Final Award, 29 June 2017, https://pcacases.com/web/sendAttach/2172.

${ }^{59}$ Aleš Bizjak, Transboundary Cooperation of the Republic of Slovenia. Obligations, Good Practices and Benefits, $2^{\text {nd }}$ Workshop on Assessing the Water-Food-Energy-Ecosystem Nexus and Benefits of Transboundary Cooperation in the Drina River Basin, Belgrade, 8-9 November 2016, https://www.unece.org/fileadmin/DAM/env/documents/2016/wat/11Nov_ 08-10_Nexus_2nd-WS_Drinabasin_Belgrade/day_3/ab_UNECE_NEXUS_BELGRADE_Transboundary_Cooperation_091116.pdf.
} 
states only in $1998 .^{60}$ In the context of this commission, a sub-commission for the Mura has been operative.

In 1995, Slovenian water experts advised the construction of a new highwater embankment in the vicinity of the village of Hotiza, as they saw the existing embankments as unfit to protect the wider area during floods. In 1996, conflicts arose regarding the respective jurisdictions: who was juridically entitled to build the embankments? Who would finance the works? Who would carry them out? The Slovenian water management authorities decided to build the embankments only on the territory of the Slovenian cadastre, in order to avoid conflicts with Croatia. Construction began in May 1997. However, the Croatian police intervened and interrupted the works. Negotiations within the framework of the bilateral commission did not produce any results: the high-water embankments were not built. ${ }^{61}$ In August 2005, massive floodsproved the necessity of the planned embankments. Firefighters and volunteers managed to consolidate the existing embankments with great effort, and the floods were mainly confined within flood dams. Nevertheless, more than three hundred houses were flooded, and more than $400 \mathrm{~km}$ of local roads were damaged. ${ }^{62}$

After the border incidents of 2006 and the new bilateral agreement of 15 September 2006, the 'Permanent Slovenian-Croatian Commission for Water Management' began to prepare suitable solutions for the joint construction of the embankments. A Slovenian-Croatian consortium for the reconstruction of the flood dam on the left bank of the River Mura was established in order to build the embankment on the section from Kot to Hotiza. Construction began on 10 October 2006 and ended on 26 September 2007.63

Over the following years, the Slovenian and Croatian water management authorities continued to cooperate in the River Mura region, but they could not avoid the troubles related to the unsolved border question. A new wastewater treatment plant was built in the Slovenian village of Razkrižje in 2013, financed by EU funds. The Razkrižje municipality and the neighbouring Croatian community of Štrigova submitted an official request to both governments for cross-border cooperation. According to their plan, the Croatian municipality of Štrigova should join the Razkrižje sewage system in order to rationalize the wastewater treatment costs of both communities. Unfortunately, this

${ }^{60}$ Uredba o ratifikaciji Pravilnika stalne slovensko-hrvaške komisije za vodno gospodarstvo. Uradni list Republike Slovenije 11/1998.

${ }^{61}$ Tomaž Globokar et al., Urejanje, vzdrževanje in obratovanje vodne infrastrukture ter vzdrževanje vodnih in priobalnih zemljišč na mejnih vodotokih, Mišičev vodarski dan 17 (2006), 1-25, 14-15.

${ }^{62}$ Blaž Komac/Karel Natek / Matija Zorn, Geografski vidiki poplav v Sloveniji, Ljubljana 2008, 138.

${ }^{63}$ Zapisnik XI. zasedanja Stalne slovensko-hrvaške komisije za vodno gospodarstvo. 
was not realized. Both communities waited more than three years for the necessary official permits from the national and bilateral institutions and commissions. In September 2017, the local Croatian water management company decided to withdraw from the agreement and began preparing its sewage system. This termination of cooperation was not rational from a local Croatian perspective: by cooperating, the municipality of Štrigova would have saved about a million euros. ${ }^{64}$ The mayor of the municipality of Razkrižje has placed responsibility for the cancelled cooperation on the deterioration of the relations between the two countries following the PCA arbitration. ${ }^{65}$

\section{The Administrative Legacy of the River Mura}

The Mura has been a border river since the middle of the $13^{\text {th }}$ century, when the border between the Holy Roman Empire and the Kingdom of Hungary was established between the towns of Radgona and Ljutomer (today's Slovenian inner River Mura). ${ }^{66}$ In the Middle Ages, the river on this stretch of land was also an important economic and geographic factor. In view of its nature, however, it could only delineate a border with a zoning character. As the first recorded border dispute of 1233 proves, medieval protagonists used the natural might of the river for strategic and military purposes. In that year, the Styrian forces dammed the river, which caused several villages on the Hungarian side to be flooded. The situation was remedied by a Hungarian dignitary who tore down the dam and restored the previous conditions. ${ }^{67}$ In the course of the centuries, disputes between the inhabitants of the two river banks often arose due to the Mura's inconstant flow, as another example of the first half of the $16^{\text {th }}$ century proves. ${ }^{68}$ In 1755 , during the reign of Habsburg Empress Maria Theresa, the border between Hungary and Styria was settled, and especially so in the upper part of the River Mura, between Radgona and Mota. ${ }^{69}$ Dams were built and border stones placed, in order to mark the border between the two political entities. The latter, however, would often be removed by the river itself, during floods. ${ }^{70}$

\footnotetext{
${ }^{64}$ Bojan Peček, Hrvati nočejo slovenske čistilne naprave, MMC / RTV Slovenija, 11 September 2017, https://www.rtvslo.si/lokalne-novice/hrvati-nocejo-slovenske-cistilne-naprave/432281.

${ }^{65}$ Odločitev Međimurskih vod o gradnji lastne čistilne naprave za Štrigovo, Občina Razkrižje, 8 September 2017, http://www.razkrizje.si/odlocitev-medimurskih-vod-o-gradnjilastne-cistilne-naprave-za-strigovo/.

${ }^{66}$ Milko Kos, Srednjeveški urbarji za Slovenijo, Urbarji Salzburške nadškofije, Ljubljana 1939, 12.

${ }^{67}$ László Mayer/András Molnár, eds, Viri za zgodovino Prekmurja 1. Források a Muravidék történetéhez 1, Szombathely, Zalaegerszeg 2008, 45.

${ }^{68}$ Ivan Zelko, Zgodovina Prekmurja. Izbrane razprave in članki, Murska Sobota 1996, 65.

${ }^{69}$ Zelko, Zgodovina Prekmurja, 68.

${ }^{70}$ Fran Kovačič, Ljutomer. Zgodovina trga in sreza, Maribor 1926, 25.
} 


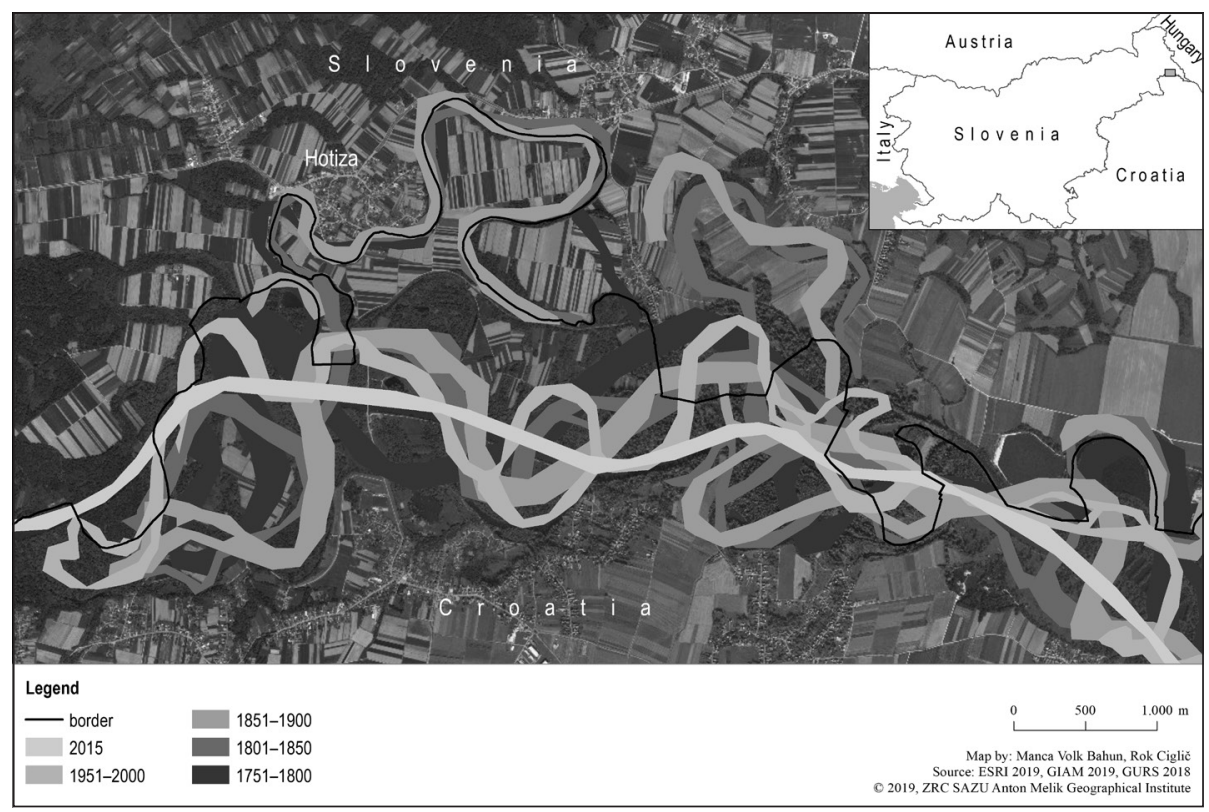

Figure 2: Meanders of the Mura river bed near Hotiza in different periods

In the $19^{\text {th }}$ century, the late Habsburg Empire introduced the most important invention for the construction of more precise administrative borders: the Land Tax Cadastre (Grundsteuerkataster). A cadastre is an official register of land lots in a certain area with regard to their form, scope, quality, crops, and property. Cadastral municipalities can be traced back to the beginnings of the Josephine Cadastre (1785). ${ }^{71}$ Most important for the construction of administrative borders was the Franciscan Cadastre, introduced by an Imperial Order of 1817. The central Slovenian territory was measured between 1818 and 1828, while today's Prekmurje region, that is the region beyond the River Mura to the east, was measured only after $1850 .^{72}$ The Franciscan Cadastre also included cadastral maps. ${ }^{73}$ The measurement itself was very precise for the circumstances of the time, and the Franciscan cadastral municipalities represent the basis for all subsequent cadastral measurements to date. ${ }^{74}$ Since their beginnings, the cadastral municipalities have been much more than a simple acces-

\footnotetext{
${ }^{71}$ Jože Žontar, Struktura uprave in sodstva na Slovenskem od srede 18. stoletja do leta 1848, Ljubljana 1998, 131.

${ }^{72}$ Peter Ribnikar, Zemljiški kataster kot vir za zgodovino, Zgodovinski časopis 36, no. 4 (1982), 321-337, 324.

${ }^{73}$ Ribnikar, Zemljiški kataster, 329.

${ }^{74}$ Miha Seručnik, Reambulančni kataster za Kranjsko, Kronika. Časopis za slovensko krajevno zgodovino 57, no. 3 (2009), 491-504, 492.
} 
sory of tax policies. The state invented them in order to control and make use of the population: in essence, the cadastral municipalities are enforced imperial spaces-tiny but efficient spaces of authority and control. They still represent the smallest integral territorial unit of the state in the successor countries of the former Habsburg Monarchy.

The River Mura between Radenci and Razkrižje (today's Slovenian inner Mura) was not just the border between Habsburg Styria, in the Austrian part of the Double Monarchy, and Hungary, but also the border between two different coordinate systems of land survey. The left and the right banks of the Mura were measured separately, according to the different origins of the respective coordinate systems. The Styrian survey had its origin in Schöcklberg, close to Graz, while the Hungarian survey originated from the hill Gellert, close to Budapest. Because of the different coordinate systems and the different times of measurements-the Mura's river bed continued to change-irregularities appeared on maps, especially on those of the Franciscan Cadastre and of the second military survey conducted in the Habsburg Empire (1806-69). Some irregularities were corrected by geometric surveyors during the $20^{\text {th }}$ century; others remain to date. ${ }^{75}$ According to geodesy literature, the incompatibility of the cadastral borders, as caused by the different coordinate systems in the $19^{\text {th }}$ century, does not represent significant problems for contemporary border setting. More problematic, this literature says, are the measurements of cadastral municipalities carried out during the $20^{\text {th }}$ century, because these were done without the participation of representatives of the neighbouring cadastral municipalities. ${ }^{76}$

The notion of rivers as perfect 'natural borders' was developed in the $19^{\text {th }}$ century, in the 'age of nationalism'..$^{77}$ In the Habsburg Empire, the creation of state dualism in 1867 (the creation of Austria-Hungary) changed the status of the border on the River Mura. From then on, the border separated the two semi-independent halves of the empire, which were joined together only by a common foreign policy, financing, and the military. ${ }^{78}$ For the lives of the people along the river, it was especially important that the border separated two different legal systems. These differences in legislation created

${ }^{75}$ Anka Lisec/Gerhard Navratil, Avstrijski zemljiški kataster. Od prvih začetkov do sodobnega zemljiškega informacijskega sistema, Geodetski vestnik 58, no. 3 (2014), 482-516, DOI: 10.15292/geodetski-vestnik.2014.03.482-516; Lesjak, Mura skozi čas, 187.

${ }^{76}$ Zupančič, Zemljiški kataster, 42.

77 Beata Halicka, Flüsse als 'natürliche Grenzen'. Das Erbe des europäischen Nationalismus am Beispiel Rhein, Oder und Weichsel, in: Rita Aldenhoff-Hübinger/Catherine Gousseff/Thomas Serrier, eds, Europa vertikal. Zur Ost-West-Gliederung im 19. und 20. Jahrhundert, Göttingen 2016, 87-101.

${ }^{78}$ Helmut Rumpler, Österreichische Geschichte 1804-1914. Eine Chance für Mitteleuropa. Bürgerliche Emanzipation und Staatsverfall in der Habsburgermonarchie, Wien 1997, 411. 
both obstacles and opportunities for cross-border relations. ${ }^{79}$ Međimurje, the area between the Styrian-Hungarian border and the rivers Mura and Drava, remained an object of dispute between 1848 and 1918 between the central Hungarian authorities in Budapest and the Croatian autonomous authorities. ${ }^{80}$ In 1848, the Croatian leader, ban Josip Jelačić, annexed Međimurje to the Croatian administration, but in 1861 the Hungarian government excluded it from Croatian autonomy. ${ }^{81}$ The above-mentioned region of Prekmurje, on the other hand, existed at the time only as a concept in the minds of Slovenian nationalists, as 'the Slovenian land' on the other (Hungarian) side of the River Mura. ${ }^{82}$

After the First World War, in the tumultuous times of the establishment of new states on the rubble of the Habsburg Empire, which saw the formation of new state borders between 1918 and 1920, the status of the border at the River Mura changed several times. On 12 August 1919, the Army of the Kingdom of Serbs, Croats, and Slovenes occupied the Prekmurje region, and this territory on the left bank of the Mura was finally annexed to the Yugoslav state with the Treaty of Trianon (4 June 1920). It is interesting that during the occupation between August 1919 and June 1920, the border at the Mura was not abolished, but instead strengthened. The passage of the inhabitants of Prekmurje over the River Mura into Yugoslavia proper was only possible with permits. ${ }^{83}$

After the consolidation of the new states in the region by 1920, the River Mura retained its status as a border river, only now that status referred to a different section and to a different country. The new border between Austria and Yugoslavia was established on the River Mura between the towns of Spielfeld and Radgona, while the section of the river between Radgona and Podturen (in today's Croatia) - the point where the border with Hungary began-now became the inner river of the Kingdom of Serbs, Croats, and Slovenes. Thus, the section of the river between Radgona and Razkrižje lost its border status after more than five hundred years. Today's border between Slo-

\footnotetext{
${ }^{79}$ Gunter Schall, Der österreichisch-ungarische Dualismus als Integrationskonzept, Hamburg 2001, 151.

${ }^{80}$ Danijel Jukopila, Rijeka Mura. Čimbenik oblikovanja regionalnog identiteta, Ekonomska i ekohistorija. Časopis za gospodarsku povijest i povijest okoliša 9, no. 1 (2013), 56-66, 58, https://hrcak.srce.hr/114484.

${ }_{81}$ Mirjana Gross/Agneza Szabo, Prema hrvatskome građanskom društvu. Društveni razvoj u civilnoj Hrvatskoj i Slavoniji šezdesetih i sedamdesetih godina 19. stoljeća, Zagreb 1992, 37-38.

82 Jernej Kosi, Slovenski nacionalni prostor na Ogrskem. Ustvarjanje zamisli o slovenskohrvaški meji v dolgem srednjeevropskem 19. stoletju, in: Zajc, ed, Ustvarjanje slovenskohrvaške meje, 29-46.

${ }^{83}$ Vanek Siftar, Prekmurje 1918-1920, Časopis za zgodovino in narodopisje 61, no. 1 (1989), 33-53, 49, http://hdl.handle.net/11686/7036; Rudi Kyovsky, Trianonska pogodba in slovensko-ogrska meja, in: Janko Liška, ed, Revolucionarno vrenje v Pomurju v letih 1918-1920, Murska Sobota 1981, 236-259.
} 
venia and Croatia was non-existent at the time, since no Slovenian or Croatian political unit existed in the framework of the Kingdom of Serbs, Croats, and Slovenes, which would be renamed the Kingdom of Yugoslavia in 1929.

Nevertheless, for the future development of the borders attached to the River Mura, the administrative division within the Kingdom of Serbs, Croats, and Slovenes/Yugoslavia would prove to be of the utmost importance. In 1923, the central government in Belgrade divided the country into thirty-three administrative districts (oblasts). Following a brief period of belonging to the 'Croatian' Zagreb provincial administration (1918-23), after the oblasts were formed, the entire Međimurje region became part of the 'Slovenian' Maribor oblast (1924-29). Only six years later, the oblasts were abolished. After the establishment of the Kingdom of Yugoslavia in 1929, and with it the dictatorship of King Alexander I, the banovina was introduced as the new, more centralized regional unit. Now, the Međimurje fell under the 'Croatian' Sava banovina, which had Zagreb as its headquarters. However, in 1931, the Štrigova municipality was separated from the rest of Međimurje and placed under the authority of the Ljubljana-based Drava banovina and its Ljutomer District. In 1937, the Štrigova municipality was divided into two new municipalities, Štrigova and Razkrižje - the two municipalities that after 2013 would attempt in vain to establish a common sewer system. This administrative history interestingly entangles with the history of the nationalization processes in the region. Only in post-imperial times did national differentiation begin to gain ground among the population of this part of Međimurje, and the inhabitants of Razkrižje since then seem to have favoured Slovenian identification, while the inhabitants of Štrigova were inclined towards a Croatian identity. ${ }^{84}$

During the Second World War (1941-45), the regions of Prekmurje and Međimurje were reannexed to Hungary, and subsequently (after the Soviet occupation and the arrival of the Yugoslav forces) returned to Yugoslavia: Prekmurje to the People's Republic of Slovenia and Međimurje to the People's Republic of Croatia. ${ }^{85}$ Interestingly, the villages of Štrigova and Razkrižje stood at the centre of the most significant border dispute between Slovenia and Croatia after the Second World War. After the administrative reorganization in the wake of the establishment of Yugoslavia, when they had been the only part of Međimurje that had been included in the 'Slovenian' Drava banovina, and later divided into two municipalities, both were included into the Socialist Republic of Croatia after 1945. The villagers of Razkrižje, those identifying as Slovenes, organized a campaign in order to convince the Croatian and federal author-

\footnotetext{
${ }^{84}$ Stipica Grgić, The Štrigova and Razkrižje Micro-Region in the First Half of the $20^{\text {th }}$ Century, Prispevki za novejšo zgodovino 57, no. 3 (2017), 26-43.

${ }^{85}$ Metka Fujs, Izhodišča madžarske okupacijske politike v Prekmurju, Prispevki za novejšo zgodovino 37, no. 2 (1997), 175-187.
} 
ities to annex the Razkrižje-Štrigova micro-region to the Socialist Republic of Slovenia. At the same time, most of the inhabitants of Štrigova supported adherence to Croatia. The federal authorities intervened, despite having no jurisdiction when it came to changing the borders of the republics. A special Slovenian-Croatian Commission was established in 1946 and adopted a solution according to which the northern part, or one-third of the disputed territory, should belong to Slovenia, while the southern and western parts should belong to Croatia. Interestingly, however, regardless of the dimensions of the dispute-people also expressed their discontent through petitions and gatherings-and regardless of the proximity of the villages involved, the River Mura did not play any role in this particular border dispute. ${ }^{86}$

Generally, in fact, between 1945 and 1991, the Mura did not 'actively' appear in international or inter-republican disputes. The nature of the border between the two Yugoslav federal units of Slovenia and Croatia did not call for a precise demarcation or division of jurisdiction. What would prove important for future developments was that the equation of the Slovenian-Croatian border with the cadastral border took place rather late. Given that the Yugoslav republics were defined as 'states', the border between Slovenia and Croatia could have had an administrative and state-legal character. However, in the field the boundary line was not defined precisely until as late as 1980. In that year, the legislation on municipalities changed in Slovenia so that the territories of the municipalities now corresponded to the cadastral municipalities. As the border between Slovenia and Croatia had previously been defined descriptively as running between municipalities, now the border between the Slovenian and Croatian cadastres de facto became the Slovenian-Croatian boundary line. After the two countries became independent in 1991, Slovenian land surveyors pointed out that the border according to cadastral municipalities 'will not be functional and prudent' and suggested undertaking a bilateral harmonization with the assistance of joint commissions in order to define the border. ${ }^{87}$ They saw the cadastre borders as inappropriate to function as an international border for both environmental and administrative reasons: on the one hand, the borderline crossed rivers several times; on the other hand, there were discrepancies between the Slovenian and Croatian cadastres, as described above. There were overlaps and voids in the territories where the single cadastral municipalities made contact. ${ }^{88}$

\footnotetext{
${ }^{86}$ Zdenko Čepič, Oris nastajanja slovensko-hrvaške meje po drugi svetovni vojni, in: Zdenko Čepič/ Dušan Nećak/Miroslav Stiplovšek, eds, Mikužev zbornik, Ljubljana 1999, 201-216.

${ }^{87}$ Demšar, Ureditev državne meje Slovenije s Hrvaško, 298.

${ }^{88}$ Demšar, Ureditev državne meje Slovenije s Hrvaško, 298-303.
} 
Thus, with the dissolution of Yugoslavia in 1991, the problem arose of the so-called twofold ownership on the Slovenian-Croatian border at the River Mura. The inhabitants of the village of Hotiza own considerable portions of land on the Croatian side of the border. This issue had not been problematic before, even though in socialist Yugoslavia there were differences between the taxation of property in Croatia and Slovenia. ${ }^{89}$ The Permanent Court of Arbitration's Final Award of 2017 suggested that the cadastral borders in the Mura region should be acknowledged by both countries as the state border, with one minor exception (the hamlet of Murišče). The interpretation of the Mura as the Slovenian-Croatian border river, emphasized by the Slovenian negotiation team in The Hague, was unsuccessful. The Slovenian side had counted predominantly on the division of administrative units (oblasts, banovinas) in the period of the Kingdom of Serbs, Croats, and Slovenes/Yugoslavia (192341) and the fact that the left bank of the Mura had been in the hands of the Slovenian administration until $1991 .^{90}$ However, as explained above, Croatia has not accepted the PCA's arbitration, and so the issue of the exact borderline remains open.

Another layer was added to the rich tradition of ambiguous borders and boundaries in the region in autumn 2015, when the 'anti-migrant' border fence on the Slovenian-Croatian border was constructed as a consequence of the 'refugee crisis'. The border near the River Mura became literally a wall of 'Fortress Europe'. ${ }^{11}$ The villagers of Hotiza were not happy with the erection of the razor wire border fence. They feared that placing it in this area would create new misunderstandings between the two countries and hoped that it was a temporary measure. Since most of the locals own land on the other side of the border, they were also concerned about how they would manage to cultivate their fields, through which the fence now runs. ${ }^{92}$ The Slovenian state provided them with compensation, but the amount offered was deemed far too small. ${ }^{93}$ Unfortunately, after four years, the fence is still in place. To be precise, the border fence erected by the Slovenian government does not follow the exact borderline advocated by the Slovenian government, especially near the border rivers Mura and Drava-the fence had to be erected on Slovenian terri-

\footnotetext{
${ }^{89}$ Belec, Hrvaška zemljiška posest, 186.

${ }^{90}$ PCA Case No. 2012-04, 125.

${ }^{91}$ Cf. Veronika Bajt's contribution to this thematic section. Cf. also Veronika Bajt/ Mojca Frelih, Crimmigration in Slovenia, Dve domovini / Two Homelands 49 (2019), 7-25, 13, DOI: $10.3986 /$ dd.v0i49.7251.

${ }_{92}$ Samanta Gomboc, Domačini ob bodeči žici se počutijo kot v vzporednem svetu, Sobotainfo, 16 November 2015, https://sobotainfo.com/novica/lokalno/domacini-ob-bodecizici-se-pocutijo-kot-v-vzporednem-svetu/116365.

${ }_{93}$ Oste Bakal, Odškodnina za žico le miloščina, Slovenske novice, 1 January 2019, https:// www.slovenskenovice.si/novice/slovenija/clanek/odskodnina-za-zico-le-miloscina-133383.
} 
tory. As a consequence, two different variations of the border came into existence in 2015: on the one hand, the administrative borderline, as marked in the official registries, as of yet unconfirmed due to the dispute with Croatia; and on the other hand, the unofficial borderline of 'bordering practice' in the landscape, which is becoming permanent due to the inability of the EU to tackle the issue of migration. ${ }^{94}$

\section{Phantom Borders and Administrative Legacies}

The two concepts of 'phantom borders' and 'administrative legacies' help us to approach the interlacing of administrative and environmental issues in this case study. 'Phantom borders', as they were originally invented, refer to former political borders that continue to structure the present. In many cases, historical spaces such as the Habsburg Monarchy, the Ottoman Empire, Yugoslavia, the Polish divisions, or divided Germany 'keep returning' in the form of social practices, electoral geographies, infrastructural networks, and so on. ${ }^{95}$

Although the concept of 'phantom borders' includes the word 'border', it is really a tool to research spaces, spatial practices, and agency. Similarly, Border Studies has recently been inclined to see borders as a belief, an imagining that creates and shapes social realities. The emphasis is on people and their practices, strategies, and motives. ${ }^{96}$ Last but not least, Border Studies has recently evolved as a multidisciplinary response to $20^{\text {th }}$-century political history and political geography, which were predominantly descriptive, understanding borders in a material sense, as objects of study, and were consequently uninterested in social and political processes. ${ }^{97}$

However, as I have demonstrated above, it might be time to shift the attention back to borders as objects, as political divisions ('lines') registered both in spatial projections such as (cadastral) maps and as infrastructure in the landscape itself (fences, border stones). ${ }^{98}$ The 'phantom border' concept was devel-

\footnotetext{
${ }_{94}$ Bajt / Frelih, Crimmigration in Slovenia, 23.

${ }^{95}$ Hannes Grandits et al., Phantomgrenzen im östlichen Europa. Eine wissenschaftliche Positionierung, in: Béatrice von Hirschhausen et al., eds, Phantomgrenzen. Räumen und Akteure in der Zeit neu denken, Göttingen 2015, 13-56; cf. also my Introduction to this thematic section.

${ }^{96}$ Hastings Donnan / Madeleine Hurd / Carolin Leutloff-Grandits, Introduction. Crossing Borders, Changing Times, in: Madeleine Hurd / Hastings Donnan / Carolin LeutloffGrandits, eds, Migrating Borders and Moving Times. Temporality and the Crossing of Borders in Europe, Manchester 2017, 1-24, 2.

97 Thomas M. Wilson/Hastings Donnan, Borders and Border Studies, in: Thomas M. Wilson / Hastings Donnan, eds, A Companion to Border Studies, Oxford 2012, 1-26, 9.

${ }_{98}$ Ramya Swayamprakash, Drawing a Line on Water. The Administrative Legacy of the Detroit River Border, lecture at the conference 'Borders and Administrative Legacy', Ljubljana, 24-26 November 2016. A video of the lecture is available at sistory.si, http://hdl.
} 
oped in order to research the influence of former political borders on present social realities. My work on the history of the Slovenian-Croatian border suggests that the concept can be evolved to apply also to research on existing political borders. Every political border contains a reminiscence of its past, and every redefinition of a border involves its past. Among other things, borders are the 'physical record' of the history of states. ${ }^{99}$ If the 'phantom border' metaphor is to work as a theoretical tool for understanding contemporary borders, it needs to be fuelled with the concept of 'administrative legacy', that is with a border's paper trail, in the form of documents kept in official state registries and archives. It is thus closely connected to the development of the modern territorial state. ${ }^{100}$

In postwar Europe, the legitimacy and meaning of borders were in fact established on the basis of the bare records: borders were established because they had been there before. Consequently, the political aim was that borders should not be changed. In Western Europe, the initiators of European integration accepted the postwar status quo and set out to replace interstate war with interdependence. The alternative to potential wars to change borders in the future was the acceptance of the state boundaries produced by the postwar balance of power and the development of interdependence across frontiers. ${ }^{101}$ Sure enough, the international borders in Europe have changed frequently since the end of the Second World War. Some were abolished, such as the German-German border; others were no longer subject to a border regime because they were included in the Schengen system. Some gained international status after the dissolution of multinational states, such as in Yugoslavia's successor states; others became an expression of 'Fortress Europe' through razor wire fences after the 2015 'refugee crisis'. Changes of borderlines through the creation of internationally unrecognized states aside (see Alexandru Lesanu's contribution to this thematic section), the course of borderlines as such has hardly changed in post-World War II Europe.

However, as demonstrated in this study, political borders may outlive the existence of the states that created them. In this sense, borders are more resilient than states. When it comes to borders in post-Habsburg Central Europe,

handle.net/11686/37255; Marko Zajc, Obsedena meja. Predgovor, in: Zajc, ed, Ustvarjanje slovensko-hrvaške meje, 5-12.

99 Thomas M. Wilson / Hastings Donnan, Nation, State and Identity at International Borders, in: Thomas M. Wilson / Hastings Donnan, eds, Border Identities. Nation and State at International Frontiers, Cambridge 1998, 1-30, 9.

100 Monika Eigmüller, Der duale Character der Grenze. Bedingungen einer aktuellen Grenztheorie, in: Monika Eigmüller/Georg Vobruba, eds, Grenzsoziologie. Die politische Strukturierung des Raumes, Wiesbaden 2006, 49-68, 57.

${ }^{101}$ Liam O'Dowd, The Changing Significance of European Borders, in: James Anderson / Liam O'Dowd / Thomas M. Wilson, eds, New Borders for a Changing Europe. Cross-Border Cooperation and Governance, London, New York/NY 2003, 13-26, 17. 
the cadastral municipalities have proven to be the most important administrative legacy. The Habsburg Empire, the Kingdom of Serbs, Croats, and Slovenes/ Yugoslavia, as well as socialist Yugoslavia, have all contributed layers to the overall administrative legacy of the contemporary Slovenian-Croatian border.

So where precisely does the 'phantom' hide when it comes to contemporary borders? How do contemporary borders become possessed with a 'phantom' from the past? A border succumbs to such 'possession' when the constellation of the political spaces changes, or when new spaces are created, leaving the old ones to 'fade out' into the past, as for example when Yugoslavia broke up. As Brendan O'Leary noted, a secession-in contrast to a partition-involves a border transformation, the conversion of a previously internal border into a sovereign demarcation. ${ }^{102}$ In that moment a crack may open in the 'border fabric' and the 'phantom' past may ooze out of it, 'possessing' the border.

This is apparent on two levels. On the one hand, through representations and discourses an 'external' historical 'phantom' may 'possess' the border, that is to say that the new nature of the border results in altered representations of it. The border may either lose importance at the discursive level, or gain it. New historical narratives and media discourses are formed that (re-)define the border in the context of the newly created space. On the other hand, there is the level of administrative legacy, that is to say that the border may be 'possessed' by its historical 'phantom' from 'within'. The administrative legacy is its 'phantom' past, structured through official state records. As such, the 'phantom' literally represents 'the old contained in the new'. Administrative legacy is 'hidden phantomness'. It is material in the sense of what has been preserved and recorded-something that 'never dies' but also never remains the same. Each time it comes to life, it acquires a different form and effect. As the political space changes, those parts of the administrative legacy that were once banal, technical, even obscure-such as, specifically, cadastral municipality borders-can become a matter of national interest.

\section{Conclusion}

Rivers call for certain human activities. Rivers that often change their beds due to hydrological and geomorphological characteristics (meandering, dead river branches, gravel bars) are active 'in themselves' and call for more human response activities than rivers with relatively stable river beds. In the case of border rivers, such activities become more complicated: they require communication and coordination between the two states (or other political entities) separated by the river. River regulation calls for coordinated works and

${ }^{102}$ Brendan O'Leary, Partition, in: Wilson / Donnan, eds, A Companion to Border Studies, $27-47,31$. 
expenses. If these are lacking, authorities on both sides of the river border frequently delay the intervention, often to the detriment of the population on both sides of the border. In addition, the history of regulation on a given border river proves to be of exceeding significance, especially in cases where the river only recently gained the status of a border river. In such cases, the history of previous regulations is an essential part of the border's legacy.

'Common sense' ideas about border rivers imply that the river bed and the boundary line usually match. As my case study shows, this is an over-simplification. The actual landscape and their cartographic representations can significantly differ through time. They are mutually dependent, however: boundary lines are usually defined on the basis of a river's bed. In turn, boundaries may even influence a river bed. In any case, border rivers that change their river beds are prone to cause border disputes. The environmental 'phantom' is the longue durée border river status that has affected the shape and dynamics of the river bed; the administrative 'phantom' is the former river beds as marked on cadastral maps. The two combined re-enforce their 'phantom' potential, prone to 'possess' the present when the changing political context allows for it.

\section{Corresponding author}

Marko Zajc Institute of Contemporary History, Kongresni trg 1, 1000 Ljubljana, Slovenia.

E-mail: marko.zajc@inz.si 